\title{
The Escalating of Numbers of Foreign Workers in Construction Site
}

\author{
Norazlin Mat Salleh ${ }^{1}$, Shahela Mamter ${ }^{2}$, Nor Suzila Lop ${ }^{3}$, Izatul Farrita Mohd Kamar ${ }^{4}$, Noor \\ Aishah Mohamad Hamdan ${ }^{5}$ \\ 1,2,3,4,5 Department of Quantity Surveying, Faculty, Architecture, Planning and Surveying, Universiti \\ Teknologi MARA (Perak), Malaysia.
}

\begin{abstract}
This paper is evaluating the factors effecting the increasing in the numbers of foreign workers on site. A critical review of the literature was abstract because of the Malaysian economics is booming and the characteristics of the construction industry itself make the foreigners comfortable works on site. This paper discusses the results from the conducted questionnaire survey among the contractors in Selangor. Based on the average index, there are several factors identified by the respondents such as shortage of manpower, reluctant of local labour, project increased the demand for labour and accelerating economic development. This factor will improve the decision making process in recruiting labour on site.
\end{abstract}

\section{Introduction}

Generally, Malaysia has achieved a successful economic growth and full employment. Although the Malaysian economic situation showed a good performance during the normal period, the Malaysian economy actually faced a tight situation in the labour market. The demand for labour is high. According to Che Amat [1] the projects under the 10th Malaysian Plan (10MP) and Economic Transformation Programme (ETP) include Mass Rapid Transit (MRT) which will cost over RM40 billion. Such projects usually require up to 130,000 skilled construction workers in various trades.

Nowadays, due to the local workers are unable to fulfill the demand of the construction market. The Malaysian construction industry has been experiencing a critical shortage of workforce. Hence, the contractors are willing to import foreign workers to meet the needs and requirement of the labour market in the construction sector, which is indirect, contributes to the escalating number of the foreign workers. Therefore, the escalating has continually from time to time.

\section{Literature Review}

There are many factors that influencing the increase of foreign workers in construction site such as weak enforcement, unethical practice by the authority, tourism policies that will not limit visitor, high foreign labour ratio, employer abuse of work permits and economic policy of border less world. The most favourable factor influencing the increase foreign workers in construction site is distinguished foreign labour ratio. All these factors will affect the employment of the foreign worker in a construction site. 


\section{An Overview of Foreign Workers in Malaysia}

Generally, Malaysia has achieved a booming economic growth and full employment. Despite the fact that the Malaysian economic situation showed a good performance during the normal period, the Malaysian economy actually faced a tight situation in the labour market. The demand for labour is high. As according to Che Amat [1] the projects under the 10th Malaysian Plan (10MP) and Economic Transformation Programme (ETP) include Mass Rapid Transit (MRT) which will cost over RM40 billion. Such projects usually require up to 130,000 skilled construction workers in various trades.

Currently, due to the local workers are unable to fulfil the demand of the construction market. The Malaysian construction industry has been experiencing a critical shortage of workforce. Hence, the contractors are willing to import foreign workers to meet the needs and requirement of the labour market in the construction sector, which is indirect, contributes to the escalating number of the foreign workers. Therefore, the escalating has continually from time to time.

As described by Kassim [2] in an increasingly globalised world, the flow of workers (and their dependents) across borders are expected to accelerate and the volume will certainly increase. As long as there is demand for such workers in Malaysia, the inflow of overseas manpower will continue especially if the economic development in the neighbouring countries continues to lag behind that of Malaysia. The more restrictive the policy on foreign workers, the more will be the number of illegal employees. Hence it is necessary to adopt a less restrictive policy predicated on the assumption that the employment of foreign workers is a long term measure.

In the Population Census 1991, foreigners account for $4.4 \%$ of the Malaysian population of over 18.3 million. By 2000 , the alien population increased to over 1.384 million or $5.9 \%$. It is believed that census figures on foreign nationals are understated as it is well known that many of the illegal residing in the country at the time of the census, refrained from enumeration for fear of being identified and deported. Out of a total over 1.38 million foreigners in the country in 2000 , only about 820,000 were registered as employees and expatriates with the Department of Immigration, less than 100,000 refugees and around 30,000 foreign students. The remaining numbers, around 435,000 are most likely illegal immigrants [2].

From a peak of around 1.5 million in 1997, the number of registered foreign workers fell to a low of around 800,000 by 2000 . With economic recovery, the number of registered migrant workers in the Peninsula has once again risen to around 847,000 in 2002 and to 1.1 million in 2003. As in December 2005, this figure stood at 1.9 million [3].

Navamukundan [4] indicated that as at July 1999, the total number of registered foreign workers according to the government was 715,145 of whom $73 \%$ were Indonesians, $19 \%$ Bangladeshis, 3\% Filipinos and the remainder from other nations such as India, Myanmar, Pakistan and Sri Lanka. However, all the Malaysians are aware that the actual number of foreign labour far exceeds this number. It is estimated that approximately 1.5 million foreign labours (both legal and illegal) work in Malaysia.

In mid-2001, the population of Malaysia numbered 23.8 million, with 33 percent under the age of 15. It is projected that the population will grow to 33.7 million in 2025 . The labour force increased from 9.6 million in 2000 to 9.9 million in 2001. Migrant labour makes up approximately 20 percent of the Malaysian workforce. The country currently has between 1.7 million to two million foreign workers, of whom 770,000 are legal. The foreign workers are primarily from Indonesia, the Philippines, Bangladesh, Burma, Thailand, and India. They are employed in factories, in the construction industry, and on plantations

Saleh [5] describes based on Labour Force Survey Report for 2005, there were 6.47 million employed persons in Malaysia of which 12.9 per cent were in construction industry, 673,900 were Non-Malaysian citizens and 8 per cent from Non-Malaysian citizens were in construction industry. As of June 2006, there were 1.84 million registered foreign workers of which 33.3 percent were employed in manufacturing, plantation (20.2 per cent), services (including domestic maids) (25.9 per cent) and construction sector (15.1 per cent). 
Kanapathy [3] describes that contract migrant workers account for about 22 per cent of the Malaysian labour force. This is a relatively high percentage compared to other countries in East Asia that rely on imported labour. Contract migrant workers are at the lower end of the skills spectrum and they account for approximately 98 per cent of the total number of migrant workers in the country. Of the estimated 2.5 million contract migrant workers, an estimated 0.7 million or almost a third are clandestine or irregular migrants. The majority of migrant workers are from Indonesia (68.9 per cent), followed by Nepal ( 9.9 per cent), India (6.9 per cent) and Myanmar (4.6 per cent). The manufacturing sector employed most of the migrant workers (29.9 per cent), followed by the plantation sector (19.8 per cent), domestic services (17.1 per cent) and construction (14.5 per cent).

On May 2011, Malaysia has approximately 1.9 million foreign workers spread across sectors such as manufacturing (39\%), construction (19\%), plantation (14\%), housemaids $(12 \%)$, services $(10 \%)$, with the rest in agriculture. The contributing countries by rank are: Indonesia $(50.9 \%)$, Bangladesh (17.4\%), Nepal (9.7\%), Myanmar (7.8\%), India (6.3\%), and the rest of Vietnam. Home Minister Datuk Seri Hishammuddin Hussein had announced that the government plans to reduce the number of foreign workers to 1.5 million in three years. If we were to account for another 2 million illegal foreign workers, the number is explosive considering Malaysia such a small job market [Abdul Hamid (1)].

In observation from the research by the previous researchers above, it certainly shows that the continually escalating in number of foreign workers in this country. Foreign labour has become an integral part of the Malaysian labour forces, particularly in the construction industry. There are many estimates of foreign workers in Malaysia, but the data on the number of foreign workers have to be interpreted with caution because there is no foolproof study or survey giving exact number. From year to year, the number of foreign employees in construction site keeps accelerating due to many factors involved.

When the acceptance of foreign workers is expanded, they may reside permanently. Most of them will go back after a short working. But, it is possible for foreign workers to inflow into Malaysia and to be accumulated by various informal ways, such as their staying in Malaysia, marrying, calling a family to Malaysia, and giving birth. The actual total number of foreigners in this country must of course be larger. In addition to the workers, there are also members of their families, i.e. wives, children, aged parents and other relatives whom they have smuggled in. Many of these relatives are not in the workforce and therefore not accounted for in the registration exercise which was aimed only at those in employments and not at aliens in general. This situation consequently contributes to escalating in number of foreigners in Malaysia.

\section{Factors That Contribute To the Escalating In Numbers of Foreign Workers on Site Development Projects}

The implementation of several strategic infrastructure development and urban development projects increased the demand for labour, especially in the construction sector [4]. According to [3] oil palm, construction and electronic sectors are the principal engines of growth, and these sectors heavily depend on low-skilled migrants to remain profitable and competitive. Therefore the uses of the foreign workers in the construction site in this country are important due to reluctance by the local to do the works. Other than that, there are many more factors that have contributed to the employment of foreign workers as below.

\subsection{Economic Factor}

Malaysia is attractive because of its relatively better economic performance and prospects for foreign labour. Owing to greater industrialization and urbanisation in the economy there has been a massive rural-urban migration drift, which in turn has led to an acute shortage of workers. As a fast developing and progressive nation, Malaysia holds a better prospect for the prospective immigrants. 
The demand for labour has been increasing continuously in tandem with economic progress. Navamukundan [4] also indicated that the accelerated economic development programmes and the sustained high economic growth rates in Malaysia over approximately three decades caused the influx of foreign workers to meet the increasing demand in the Malaysian labour market.

\subsection{Labour Shortage}

Malaysia, which has tremendous shortages of manpower in the construction industry, the importation of foreign workers could initially fill up the vacancies or at least minimize the extent of manpower shortage. The supply of this additional labour force fulfilled the urgent demand for labour which could not be met so quickly and a 'cheaper rate'. In addition, it is also supported by the President of the Master Builder Association of Malaysia (MBAM), the shortage of skilled construction workers is very crucial issues in the construction industry [6]. MBAM also stated that, the acute shortage of skilled workers in the construction industry will give negative impact towards the projects under 10MP and ETP [7].

\subsection{Local Reluctance}

Presently, job opportunities generally fulfilled by the foreign workers compare to the local. This situation happens due to local attitudes which are reluctance of local in doing the jobs. There are several factors that influence to the poor participation of local labour in the construction industry.
a) Local prefer easier jobs
b) Poor images of constructions jobs
c) Poor working conditions
d) Unsafe and unhealthy working conditions
e) Poor Site Accommodations and Services
f) Low wage structure for construction jobs
g) Unattractive Jobs
h) Higher education levels
i) Lack of Training and Skill Formation
j) Change in Education
k) Skilled workers lured overseas

\section{Research Methodology}

Thirty three sets of questionnaire were distributed randomly to the selected contractors around Selangor. The questionnaire was sent via post, electronic mail (e-mail) and also hand delivered, with the self-addressed envelopes enclosed. All the data obtained from the questionnaires surveyed were collected and analyzed. The questionnaire method was conducted to collect the latest primary data from industry practitioners that accomplish the research objective.

On the other hands, informal or unstructured interviews likewise had been conducted to the selected contractors to obtain more detailed information regarding site operative on site. Overviews of these problems are used to design the questionnaires in preliminary stage. Finally, the observation also did via electronic media such as television and on sites itself. At the moment, when we went to the site, we could see most of the workers are foreign labour.

The primary data will be analyse by using quantitative approach after considering the types of data and the research objective. Data was analyzed based on the questionnaire received from the respondents. The questionnaires were analyzed through statistical method (descriptive statistic) using SPSS software. All the data from the questionnaire were transferred to the SPSS for evaluation. All the questions in the questionnaire have been given the answer and the respondents just need to tick the relevant answer where appropriate. Finally, the entire answer was presented based on the percentage 
frequency of the respondents and put in the table and figure. Based on that, the primary data was justified and developed.

\section{Analysis and Findings}

It is important at an early stage to decide for analysing method before developing any system of data collection. So, Statistical Analysis method has been considered to analyze the collected survey form. The data was collected by using measurement or liked scaling method. Five scale ratings were used to determine the severity of influence on project progress monitoring techniques by client, consultant and contractor.

The weighted average index analysis combines choice weights and question weights to produce a single index for all responses. Basically all it does be taking the results from the question score analysis and compute a weighted average of those results using the question weights. This study also uses Average Index Method to analyze data of survey and the finding as follows:

Table 1: Factors That Contribute to the escalating Of Number of Foreign Workers in Construction Site

\begin{tabular}{|c|c|c|c|c|c|c|c|c|}
\hline \multirow{3}{*}{ No } & \multirow{3}{*}{$\begin{array}{l}\text { Factors that contribute to the escalating in number of foreign } \\
\text { worker in construction site }\end{array}$} & \multicolumn{5}{|c|}{ Frequency Analysis } & \multirow{3}{*}{ Mean } & \multirow{3}{*}{ Rank } \\
\hline & & 1 & 2 & 3 & 4 & 5 & & \\
\hline & & \multicolumn{5}{|c|}{ No. of Respondents } & & \\
\hline 1 & $\begin{array}{l}\text { The implementation of strategic development projects increased } \\
\text { the demand for labour }\end{array}$ & 0 & 2 & 2 & 14 & 15 & 4.27 & 3 \\
\hline 2 & $\begin{array}{l}\text { Accelerating economic development and the sustained high } \\
\text { economic growth rates in Malaysia }\end{array}$ & 0 & 4 & 7 & 17 & 5 & 3.70 & 4 \\
\hline 3 & Tremendous shortages of manpower in construction industry & 0 & 1 & 2 & 7 & 23 & 4.58 & 1 \\
\hline 4 & $\begin{array}{l}\text { Reluctance of local which no longer willing to perform jobs that } \\
\text { they consider as 3-D (dirty, difficult and dangerous) }\end{array}$ & 1 & 1 & 7 & 14 & 17 & 4.36 & 2 \\
\hline
\end{tabular}

As presented in the Table 1 above, the mean or average index has clearly shown that the tremendous shortage of manpower in the construction industry is the main factor of the escalating in number of foreign labour in the construction site. It gains a very high mark at 4.58 . This probably means that as long as there were shortages of manpower in the construction industry, employer will continue to employ foreign labour in fulfilling the shortage. This statement can be supported by the followed mean or average index which gains 4.36 , the second high mark after a tremendous shortage of manpower in the construction industry. The second high mark is the reluctance of local which no longer willing to perform jobs that they consider as 3-D (dirty, difficult and dangerous).

Besides, the implementation of strategic development projects increased the demand for labour with the average index of 4.27 gains a ranking number three (3). While the lowest score 3.70 is gained by the accelerating economic progress and the sustained high economic growth rates in Malaysia. This may indicate that the economic growth rate in Malaysia is not a main reason why the number of foreign labour in the construction site was escalating. Local's reluctance to involve in the construction sector has generated the manpower shortage issues which indirectly create great opportunity for the foreign labour to enter into our local construction industry.

\section{Conclusion}

The main focus of this paper is to identify the key factors contribute to the escalating in numbers the foreign workers on site considering contractor's view point. A questionnaire survey was carried 
out within the contractor and analyzed then the result was identified. Based on the analysis it is found that the most significant factors influencing the escalating in numbers of foreign workers in the construction site are tremendous shortages of manpower in the construction industry and rapid development in Malaysia are the foremost reason and shortcut for employer in recruiting foreign worker.

\section{References}

1. Che Amat, S. (2011). 'Moving forward', CIDB Malaysia News, Issue 1.

2. Kassim, A. (2005). 'Cross-border movement of foreign workers in Malaysia: a comparative analysis', Master Builders $3^{\text {rd }}$ Quarter.

3. Kanapathy, V. (2006). 'Migrant workers in Malaysia: An overview', Towards and East Asian Cooperation Framework for Migrant Labour. Country paper prepared for the Workshop on an East Asian Cooperation Framework for Migrant Labour, Institute of Strategic and International Studies (Malaysia), Kuala Lumpur, Malaysia: 6-7 December.

4. Navamukundan, A. (2002). 'Migrant workers: Labour migration in Malaysia - Trade union views', Labour Education 2002/4, No. 129.

5. Saleh@ Aman, S. (2008). Causes of poor participation of local workers in Malaysia construction industry and strategies for improvement (Master Dissertation). University Technology Malaysia, Malaysia.

6. Abdul Latif, S. S. (2010). Skilled manpower shortage need urgent attention, MBAM Online News, 04 August, retrieved June 02, 2012.

7. Wong, P. M. (2011), Workers Shortage Could Hit ETP Plan, The Star Online, March 16, retrieved June 02, 2012.

8. Al-harthy, A.S.H. (2006). The Consultancy Fee for StructuralDesign Changes of Reinforced Concrete Building inOman. Faculty of Civil Engineering, UniversitiTeknologi Malaysia, Skudai, Johor, Malaysia. Ph.D. Thesis. 